\title{
POLITIK HUKUM DALAM PELAKSANAAN JAMINAN FIDUSIA BERDASARKAN UNDANG-UNDANG NOMOR 4 TAHUN 1999
}

\author{
Leera Sinta Mega Pamungkas \\ Program Studi Magister Ilmu Hukum, Pascasarjana, UIN Sunan Gunung Djati Bandung, Indonesia \\ Email: leera.pamungkas13@gmail.com
}

\begin{abstract}
Fidu ciary is the transfer of ownership rights to objects using the principle of trust provided that the object to which ownership rights are transferred remains the property of the owner of the object. In Law Number 42 Year 1999 the formulation of the Fiduciary Law does not yet reflect the existence of legal certainty, because the formulation of norms contained in the forum still causes a dualism of interp retation and there are articles of the Law that contradict article one with other articles. This research use qulitative approach and law method, result is fiduciary guarantee agreements have not protected creditors with strong legal protection, even though creditors also have an important role in broad economic activities and narrow guarantees. This study aims to determine the legal protection of creditors in order to achieve legal certainty in the fiduciary guarantee agreement with the juridical-normative method.
\end{abstract}

Keywords: Fiduciary, Political Law, legal certainty

\begin{abstract}
ABSTRAK
Fidu sia adalah pengalihan hak kepemilikan atas benda menggunakan asas kepercayaan dengan ketentuan bah wa benda yang menjadi hak terhadap kepemilikan dialihkan tersebuttetap menjadi hak milik pemilik benda. Dalam Undang-Undang Nomor 42 Tahun 1999 perumusan UU Fidusia belum mencerminkan adanya kepastian hukum, karena rumusan norma yang terkandung didalamnya masih menimbulkan dualisme penafsiran dan terdapat pasal-pasal UU bertentangan pasal satu dengan pasal yang lain lain. Penelitian ini menggunakan pendekatan Kualitatif dan metode penelitian hukum, menghasilkan perjanjian jaminan fidusia belum melindungi para kreditur dengan perlindungan hukum yang kuat, padahal kreditur juga memiliki peranan penting dalam kegiatan ekonomi secara luas dan penjaminan secara sempit. Penelitian ini bertujuan untuk mengetahui perlindungan hukum terhadap kreditur agar tercapai kepastian hukum dalam perjanjian jaminan fidusia dengan metode yuridis-normatif.
\end{abstract}

Kata Kunci: Jaminan Fidusia, Politik Hukum, Kepastian Hukum

\section{PENDAHULUAN}

Pada umumnya untuk memperoleh fasilitas dana pinjaman di suatu Bank, kreditur memberi beberapa persyaratan seperti pengadaan suatu jaminan dari debitur. Selain itu, undang-undang perbankanjuga mengedepankan urgensi suatu jaminan (collateral) sebagai salah satu sumber pemberian pinjaman dalam rangka mengkalkulasikan dana para nasabah yang telah terhimpun oleh pihak bank terkait, serta untuk memajukan sektor perekonomian (Lestari \& Bahmid, 2020). Jaminan yang dimaksudkan pada penelitian ini adalah agunan berupa asetbendayang bergerak dengan menggunakan jaminan fidusia sesuai dengan ketentuan Undang-UndangNomor 42 Tahun 1999 tentang Jaminan Fidusia. Dasar hukum praktek jaminan fidusia di Indonesia awalnya hanya berupa jurisprudensi dari Hge Raad

\footnotetext{
* Copyright (c) 2021 Leera Sinta Mega Pamungkas
}

This work is licensed under a Creative Commons Attribution-ShareAlike 4.0 International License. 
Khazanah Hukum, Vol. 3 No. 1: 26 - 33

Politik Hukum dalam Pelaksanaan Jaminan Fidusia berdasarkan Undang-Undang Nomor 4 Tahun 1999 Leera Sinta Mega Pamungkas

Belanda (putusan Bier Brouwerij Arrest). Saat itu pertama kalinya hakim mengesahkan regulasi mekanisme penjaminan. Kemudian dibuatlah Undang-Undang Nomor 42 Tahun 1999 Tentang Jaminan Fidusia. Dan hanya sedikit sekali referensi bagi regulasi instrumen fidusia. Sebagaimana perkara pada putusan Mahkamah Agung(MA) No. 372K/Sip/1970 mengenai perkara BNI cabang Semarang melawan Lo Ding Siang, dengan putusan No.1500K/ Sip/1978 atasperkara BNI 1946 yang menggugat Fa Megaria yang mengakui fidusia sebagai suatu instrumen jaminan.

Agar jaminan fidusia dapat mendistribusikan hak istimewa berupa preferensi bagi yang berpiutang, maka jaminan fidusiatersebut harus dibuat di depan Notarisberupa Akta Jaminan Fidusialalu dilegalisasikan ke Kantor Pendaftaran Jaminan Fidusia (Setianingrum, 2016), sehingga jikalau debitur tidak menepati perjanjian tersebut, maka kreditur sebagai akseptor fidusia memiliki hak untuk mengambil alih objek yang diagunkan atas kewenangannya dalam rangka pemenuhan atas piutang debitur. Jaminan Fidusia terbagi menjadi dua jenis bentuk jaminan yaitu agunan berupa perseorangan dan agunan berupa kebendaan (Setiono, 2018). Jaminan yang paling sering dilaksanakan oleh bank yaitu agunan berupa kebendaan. Salah satu agunan berupa kebendaan yang paling masyhur dalam hukum positif adalah jaminan fidusia. Sebagai lembaga jaminan atas barang yang bergerak, jaminan fidusia sering dijalankan oleh para pembisnis, seperti yang telah dijelaskan sebelumnya, dahulu keberadaan fidusia didasari pada putusan hakim atauyang lebih dikenal dengan Yurisprudensi.

Dalam perkembangannya sebagai lembaga agunan yang diperlukan masyarakat, fidusia bisa menyebabkan permasalahan hukum (Adnyaswari etal., 2018). Sedikitnya disebabkan beberapa hal, yaitu ketidak pastian rancangan terkait objek fidusia, ketidakjelasan sifat dari fidusia itu sendiri, tidak ada sinkronasasi dogma-dogma yang terkandung dalam perundang- undangan yang mengelola lembaga jaminan, ketidakjelasan wewenang kreditur jika nasabah yang menajukan pinjaman ingkar akan perjanjian awal, wewenang pelimpahan fidusia dan kepastian hukum bagi pihak peminjam, dan apabila terdapati likuiditas pada pihak bank atau pihak peminjam mengalami kebangkrutan.

Melalui regulasi undang-undang tersebut, hukum dapat dilaksanakan, walaupun dalam pelaksanaannya memiliki problematika. Salah satu maksud dari dibuatnya hukum ialah agar adanya kejelasan hukum (Siallagan, 2016). Dengan tiadanya kejelasan hukum maka menjadi sebuah kemustahilanjika kepentingan rakyat terpenuhi dan tidak akan terwujud harmonisasi dalam masyarakat. pada pelaksanaanya peraturan jaminan fidusia dinilai tidak memberikan kepastian hukum secarayuridis, normatifnya, ataupun dari segi sosiologis/kegunaannya. Penyebabnya, diperkirankan bahwa dari segi yuridis normatif, ketidakjelasan hukum UUJF nampak dari dogma yang terkandung menyebabkan multitafsir dan terdapat beberapa pasal yang tumpang tindih dengan pasal lain (overlapping). Beberapa kajian tentang UU Fidusia pernah di teliti oleh Suari dan Gorda (2020) tentang Penyelesaian Kredit Macet Dengan Jaminan Fidusia di Bank Rakyat Indonesia Cabang Renon, Danari (2020) Penyelesaian Sengketa Kontrak Fidusia Menurut Undang-Undang Nomor 42 Tahun 1999 Tentang Jaminan Fidusia dan Danari Setiono dan Sulistyo (2021) Cidera Janji Dalam Perjanjian KreditJaminan Fidusia, dari beberapa penelitian terdahulu tersebut belum adayang melakukan kajian pada Undang - Undang ataupun pasal - pasalyang ada didalamnya sebagai penyempurnaan penelitian pada kajian ini maka kami bertujuan untuk mengetahui perlindungan hukum terhadap kreditur agar tercapai kepastian hukum dalam perjanjian jaminan fidusia.

Dengan ditemukannya berbagai problematika tersebut menjadikan pelasaksana fidusia atau kreditor yang tidak menjalankan atau mengikuti Undang-Undang Nomor 42 Tahun 1999 mengenai Jaminan Fidusia dengan baik, yakni sesudah akta jaminan fidusia dihasilkan tidak sekaligus disertai dengan mendaftarkan ke Kantor Pendaftaran Fidusia (KPF). Perkara tersebut semakin membenarkah 
Khazanah Hukum, Vol. 3 No. 1: 26 - 33

Politik Hukum dalam Pelaksanaan Jaminan Fidusia berdasarkan Undang-Undang Nomor 4 Tahun 1999 Leera Sinta Mega Pamungkas

bahwa Undang-Undang Nomor 42 Tahun 1999 mengenai Jaminan Fidusia ialah hukum yang berlaku tak selaras dan tiada efektivitas sebab makna dari pasal yang terkandung multitafsir, justru tumpang tindih yang mengakibatkan kekaburan dalam regulasinya. Ini diperkuatdengan terdapatnyakeengganan rakyat mendaftarkan jaminan Fidusia meskipun su dah diperkuat dengan akta notaris.

\section{METODE PENELITIAN}

Metode pendekatan dalam penelitian ini mengguanakan metode yuridis normatif yaitu penelitian hukum yang dilaksanakan dengan mengedapankan studi pustaka atau data yang terkait dengan masalah penelitian sebagai referensi utama untuk ditelaah dengan cara mengadakan penelusuran terhadap peraturan perundang-undangan dan bahan pustaka yang berkaitan dengan masalah Jaminan Fidusia (Benuf \& Azhar, 2020). Jaminan fidusia a dalah hakjaminan terhadap benda bergerak baik yang berwujud maupun yang tidak berwujud dan benda yang tidak bergerak khususnya bangunan yang tidak dapat diberi hak tanggungan sebagaimana dimaksud dalam Undang-Undang nomor 4 tahun 1996 tentang Hak Tanggungan yang tetap berada dalam penguasaan pemberi fidusia, sebagai pinjaman bagi pelunasan utang tertentu, yang memberikan kedudukan yang diutamakan kepada penerima fidusia terhadap kreditur lainnya.

Makna fidusia dalam kamus bahasa Indonesia "memberikan kepemilikan atasa dasar kepercayaan", sedangkan dalam bahasa Belanda dikenal dengan istilah Fiduciare Eigendom Overdracht (FEO), Adapun maknanya dalam bahasa Inggrisnya secara utuh lebih dikenal dengan dengan istilah Fiduciary Transfer of Ownerchef (Nekit \& Zubar, 2020). Penelitian hukum yang dllaksanakan dengan metode menelaah bahan pustaka yang terdiri dari : Bahan Hukum primer Yaitu unsur-unsur yang terkaitdengan materi-materi berupa aturan yang bersifat mengikat yang terdiri dari Undang-Undang No.42 Tahun 1999 mengenai Jaminan Fidusia dan peraturan perundang-undangan lainnya yang terkait dengan jaminan fidusia. Bahan Hukum Sekunder, Yaitu materi yang menguraikan unsur-unsur yang terkandung dari materi hukum primer terdiri dari studi pustaka, hasil-hasil penelitian, pendapatparaahli hukum, internet dan sebagainya mengenai hukum fidusia (Benuf \& Azhar, 2020).

\section{HASIL DAN PEMBAHASAN}

\section{Analisis yuridis normatif muatan hukum UUJF}

\section{Esensi hukum (materi muatan hukum)}

Pasal 1 angka (2) tak sejalan dengan Pasal 1 angka (4) pada UU No, 42 Tahun 1999 mengenai Jaminan Fidusia. pengamatan yuridisnormatif bermula dari menguraikan definisi yang ditakwilkan pada Pasal 1 UUJF terutama definisi fidusia, jaminan fidusia atau benda. Timbul permasalahan apa yangmenjadi penyebab perumusundang-undang perlu membedakan definisi fidusia dan jaminan fidusia sampai timbul penafsiran ganda. Sedangkan tajuk undang-undangituadalah Jaminan Fidusia. Maka dari itu, yang patut ditakwilkan dengan benarialah definisi Jaminan Fidusia yang terkandung termasuk arti darifidusia. Pada definisi Jaminan Fidusia tak mesti dikhusukan lingkup dari benda disebabkan akan ada penjelasan terpisah pada definisi benda. Didalam UUJF, nampak terdapat ketidak sinambungan definisi benda dalam Pasal 1 angka 4 serta muatan benda dalam definisi jaminan Fidusia dalam Pasal 1 angka 2. Begitu juga, UUJF secara jelas memberikan label kepada bangunan yang tak bisa diberi hak tanggungan ialah benda tak bergerak. Kejadian ini memungkinkan menjadikan terdapat ketidakjelasan hukum dan kontradiktif 
Khazanah Hukum, Vol. 3 No. 1: 26 - 33

Politik Hukum dalam Pelaksanaan Jaminan Fidusia berdasarkan Undang-Undang Nomor 4 Tahun 1999 Leera Sinta Mega Pamungkas

dengan teori hukum pertanahan nasional yang mencangkup benda tanah saja serta benda bukantanah (Merista, 2016).

Oleh karena itu, dalam memberikan pengertian/terminologi, perlu diamati pemberiaan istilah yakni pada mulanya menetapkan unsur-unsur yang bersifat publik dari cakupan salah satu terma selanjutnya disertai unsur-unsur yang bersifat privat dari terma ituyang berbeda dengan termayang lain. Oleh sebab itu definisi jaminan fidusia bisa ditetapkan ulang yaitu "salah satu wewenang jaminan terhadap barang yang perpindahannya didasari atas dasar rasa percaya, yang kewenangannya masih tetap pada wewenangan nasabah sebagai jaminan terhadap pembayaran piutang khusus serta menyerahkan posisi utama terhadap yang memperoleh fidusia kepada kreditor yang lain (Triargono, 2017)". Lalu disebutkan bahwa definisi benda ialah semuahal yang bisa serta dipindah tangankan, benda bukan tanah yang konkret ataupun tak konkret, yang terdaftar ataupun tak terdaftar, dan gedung/hunian yang tidak bisa dija dikan wewenangyang menjadi tanggungan seperti yangtelah diatur dalam UU Nomor 4 Tahun 1996.

Pasal 2 tak sejalan dengan Pasal 38 dan Pasal 37 ayat(1) hingga ayat(3), UU Nomor 42 Tahun 1999 mengenai Jaminan Fidusia. Bisa ditemukan problematika dogma yang terkandung didalamnya yaitu peraturan yang terdapat pada Pasal 2 Undang-Undang Nomor 42 Tahun 1999 mengenai Fidusia yang menekankan aturan: "regulasi Undang-undang ini dapat diterapkan pada seluruh akad yang memiliki tujuan untuk dibebankan pada barangyang diagunkan secara fidusia". Dengan dogmayang applicable ini bertujuan dapat lebih mengatur secara hukum serta mampu melindungi secara hukum bagi masyarakat yang memiliki kepentingan sampai dirumuskan aturan yang mencakup seluruh aspekmengenaijaminan fidusia untuk memberi payung hukum terhadap kegiatan dalam sektor wirausaha yang bersifat dinamis. Tetapi, pada Pasal 38 UU No.42 Tahun 1999 mengenai Jaminan Fidusia terdapat peraturan berupa: "Selama aturan tersebut tidak tumpang tindih dengan aturan pada Undang-Undangini, segala ketentuan perundang-undangan tentang fidusia dinilai valid hingga dibatalkan, di-nasakh, atau diperbaharui".

Problematika dogma yang terkandung disebabkan Pasal 2 UU No.42 Tahun 1999 mengenai Jaminan Fidusia mengakom odir seluruh akad yang menitikberatkan benda denganjaminan fidusia (Putra, 2016). Adapun, dogma yang dilaksanakan pada kenyataannya bahkan tetap menyetujui keberadaan FE0 yang akan diambil alih olehnya. Terjadilah overlapping antara dogma yang hanya bersifat sarana dengan dogma yang dapat dilaksanakan. Semestinya FEO ditarik kemudian dihillangkan sebab telah aturan yang telah diperbaharui.

Pada sisilain, nilai yang akomodif memberipeluangyang lebar untuk digunakan oleh yang memilki wewenqang, pada nyatanya terdapat peluang lain yang trasparan agar dapat mengelak dari peraturan yang telah dikodifikasi, bermula dariaturan hukum yang berlandaskan putusan hakim yang dinilai tidak kuat dasar hukumnya saja. Perkra ini diabsahkan oleh peraturan pada Pasal 37 ayat (1) hingga ayat (3) UU 42 Tahun 1999 mengenai Jaminan Fidusia. Bersamaan dengan pemikiran ini, berakibat pada kreditor penerima jaminan\fidusia yang tak didaftarkan, masih bisa mendaftarkan yang telah menjadi kewenangannya didasari pada perjanjian para nasabah, kultur dan putusan hakim.

Pasal 11 ayat (1) UU No. 42 Tahun 1999 mengenai Jaminan Fidusia menjelaskan bahwa "suatu barang" yang dijadikan jaminan fidusiaharus dicatat, adapun Pasal 12 UU No.42 Tahun 1999 mengenai Jaminan Fidusia telah menentukan bahwa pencatatan "jaminan" fidusia seperti yang terkandung pada Pasal 11 ayat (1) di daftarkan di Kantor Pendaftaran Fidusia (KPF). Mengenai teknis pencatatan tercantum pada peraturan tersebutterdapat pencatatan "benda" jaminan Fidusia dalam Pasal 11 ayat (1) dan terdapatpencatatan "jaminan" fidusia sebagaiamanayang telah termaktub pada Pasal 12. 
Bahasan yang perlu digaris bawahi adalah, apa yang dimksud dari pencatatan suatu "benda" spesifik atau pencatatan suatu "jaminan" spesifik. Hal ini temtu memunculkan ambiguitas serta keraguan apa yang sesungguhnya yang wajib dicatat sebab pada regulasi pencatatan yang didaftarkan hanya berbentuk akta jaminan fidusia yang dikeluarkan oleh kenotariatan. Adapaun, pencatatan benda belum juga terlaksana, terutama pada benda-benda dagangan meskipun pada Pasal 11 UU No.42 Tahun 1999 mengenai Jaminan Fidusia terdapat mengenai pencatatan/ pendaftaran suatu barang. Ambiguitas itu menimbulkan enigma, apa yang dimaksud dengan pencatatan salah satu "benda" spesifik ataukah pencatatan salah satu"jaminan" spesifik (Rufaida, 2019). Ketidakjelasan dogma di pasal itu pada pelaksanaannya akan memunculkan ketidakjelasan hukum dan menimbulkan permasalahan hukum.

Pasal 15 ayat(3) dan Pasal 29 ayat(1a), Pasai29 (1b),(1c) dan Pasal 31 serta Pasal 32 UU No. 42 Tahun mengenai Jaminan Fidusia. Problematika prosedur jua berada dalam Pasal 15 ayat (3) dan Pasal 29 ayat (1) a Undang-Undang Nomor 42 Tahun 1999 mengenai Jaminan Fidusia pada dasarnya mengelola regulasi yang diterapkan oleh kreditur yang sering disebut parate executie berbenturan atas Pasal 29 ayat (1) b, (1) c dan Pasal31, diperkuat dengan Pasal 32 UU No.42 Tahun 1999 mengenai Jaminan Fidusia yang pada dasarnya mengelola regulasi eksekusi wajib atas izin penyalur fidusia mapun pelelangan atau melalui pengadilan. Parate executie bermaksud untuk membagikan keringanan kepada kreditur subjek fidusia tatkala debitur perantara fidusia melakukan pelanggaran, kreditur bisa saja melelang secara mandiri benda yang menjadijaminan fidusia dengan tidak menggunakan penghubung, kesepakatan dari pengadilan. Menurut Subekti parate executie ialah "melaksanakan atau menarik secara individual apa yang telah dalam kewenangannya, dengan artian tidak melalui hakim, yang diperuntukkan bagi suatu benda Jaminan agar berikutnya melelang bendanya secara mandiri.(Subekti, 1990:69) Adapun Tartib mengatakan bahwa, "pelaksanaan yang dilakukan secara mandiri oleh Jaminan (gadai dan hipotek) dengan tidak menggunakan peran atau intervensi pengadilan negeri, tetapi berpedoman pada pertolongan kantorlelangNegara saja(Majalah Varia Peradilan Th XI No.124 Januari 1996:150).

Terdapat ketidak selarasan Pasal 17 dan Pasal 1 ayat (1) Undang-Undang Nomor 42 Tahun 1999 mengenai Jaminan Fidusia Pasal 17, tidak diizinkan fidusia ulangan. Adapun fidusia ulang dilihat dari kacamata UU No. 42 Tahun 1999 ialah fidusia ulang oleh fasilitator fidusia, pihak peminjam ataupun penjamin pihak ketiga tak diperbolehkan terhadap barang yang berperang sebagai penerima jaminan fidusia sebab sudah menjadi kewenangannya terhadap barang itu sudah berpindah tangan pada yangmenjadi objek fidusia. Meskipun kewenangannya tidak berpindah tangan, hanya separuh dari kewenangannya yang berpindah tangan menurut Pasal 1 ayat (1) dan sesungguhnya perkara ini bisa di fidusia-kan ulang terhadap satu kreditur ataupun terhadap kreditur yang lain seperti halnya kredit sindikasi, dalam rangka pendanaan peminjaman konsorsium disebabkan penyerahan peminjamannya berada di ambang harga barang yang menjadi jaminannya.

Terdapat peraturan yang memunculkan enigma pada UU No.42 mengenai Fidusia, yaitu aturan pada Pasal 28 yang mengatur apabila terdapat banyak fidusia terhadap salah satu barang, maka wewenang utama diserahkan pada kreditur yang mencatatkan fidusia terlebih dahulu di Kantor Pendaftaran Fidusia. Benarkah fidusia kedua dapat dilegalkan, hanya saja tidak menggunakan hak prioritas? Tentu saja tidak sepeti itu. Karena fidusia kedua (fidusia ulang) tidak diperbolehkan pada Pasal 17, selain itu tanpahak prioritas berakibat pada tidak dapat dilaksanakannya fidusia.

Salah satu probabilitas ialah fidusia bisa diperuntukan terhadap banyak pihak ialah yang diserahkan bagi Pasal 8 UU No. 42 Tahun 1999 mengenai fidusia. Pasal 8 tersebut secara jelas menunjukkan adanya penyerahan fidusia terhadap beberapa objek, walaupun tak disebutkan tujuan pasal ini. Tetapi saat menelaah deskripsi resmi Pasal 8 itu, nampak memiliki tujuan yaitu penyerahan fidusia 
terhadap beberapa kreditur darisegipenyerahan kredit konsorsium. Maka, bisa disimpulkan fidusia tak dapat diperuntukkan terhadap beberapa kreditur, melainkan apabila diperuntukkan serentak berbarengan dan seluruh kreditur sama-sama mengenal keberadaan beberapa kredituritu.

\section{Susunan Hukum (Lembaga Jaminan Fidusia)}

Lembaga kantor pendaftaran Fidusia ialah otoritas Kementerian Hukum dan Hak Asasi Manusia negara ini (Nurhan, 2018). dalam regulasi Undang-Undang no.42 tahun 199 mengenai Jaminan Fidusia, sudah dibentuk aturan pejabat negara Indonesia N.86 tahun 2000 mengenai Tata Cara Pendaftaran Jaminan Fidusia dan anggaran pengeluaran Akta Jaminan Fidusia; dalam Pasal 13 disebutkan : "Kantor Pendaftaran Fidusia (pasal 12 ayat 1) bertempat pada Direktorat Jendral Administrasi Hukum Umum Departemen Kehakiman dan Hak Asasi Manusia. Adapun Keppres Rl No.139 Tahun 2000 mengenai pengadaan Kantor Pendaftaran Fidusia pada seluruh Ibukota Propinsi yang terdapat di kawasan Indonesia; Pasal 2 "Kantor Pendaftaran Fidusia di Ibukota Propinsi seperti dalam pasal 1 bertempat di Kantor wilayah Departemen Kehakiman dan Hak Asasi Manusia.

Teritorial negara Indonesia, mencakup 34 Provinsi, 410 kabupaten serta 98 tingkat kotamadya, kantor wilayah hanya mencakup 33 propinsi, bagi kantor wilayah di Kalimantan Utara belum ada. Selain itu pentingnya keberadaan kantor pendaftaran pada wilayah Kabupaten/Kota bersamaan dibantu dengan Sumber Daya Manusia (SDM) yang telah mahir. Problematika yang terjadi pada saat pendataan Jaminan fidusia, yang dimaksudkan terbentuknya pemberian data secara efisien dan mutakhir, agar mewujudkan asas publisitas dengan optima dan agar miminimalisir tidankan penyimpangan kubu ketiga serta agar langsung memenuhi kebutuhan kreditur dan debitor terutama jika tempat tinggal pemberi fidusia berada di luar negara Indnesia (Setiono \& Sulistyo, 2021). Sehingga membutuhkan anggaran yang banyak tentunya membebani pihak peminjam, justru jikalau terdapat wanprestasi mejadikan anggaran yang sangat banyak dibandingkan nominalyang digugatkan, terutama pinjaman dengan nominal sedikit.

Dengan adanya hambatan tersebut menja dikan beberapa akseptor fidusia atau kredituryang tidak ingin menggunakan maupun mengikuti UU No.42 Tahun 1999 mengenai Jaminan Fidusia dengan maksimum, ialah sesudah akta jaminan fidusia dikeluarkan tak didaftarkan secara langsung ke kantor pendaftaran fidusia (KPF). Perkara ini memperkuat UU No. 42 Tahun 1999 mengenai Jaminan Fidusia adalah aturan yang tak terbukti dan tak memiliki pilihan sebab makna pasal-pasalnya terdapatbeberapa yang multitafsir, justru tumpang tindih satu sama lain yang berdampak pada ketidakjelasan pada pelaksanaanya. Perkara ini bisa diuji dengan reaksi dari rakyat yang tak mematuhinya, masyarakat berpikiran menghabiskan waktu, pelaksanaanya tidak praktis, memakan waktu serta anggaran yang banyak (Yasir, 2016). Sedangkan pada sisi kacamata kompetisi nasional dan internasional, berdampak terhadap kecakapan atau ketapatan waktu wirausaha. Hambatan dapat memepengaruhi sektor ekonomi anggaran banyak sampai defisitnya persaingan pengusaha Indonesia pada sektor global.

\section{Legal Kultur (Budaya Hukum)}

Esensi dari materi hukum yang ideal tak melulu memberi kepastian terhadap terwujudnya aturan hukum, manakala tak didapati sistem hukum (isnstitusi /penegak hukum) yang bisa dijadikan acuan agar terwujudnya hukum yang dibuat. Oleh sebab itu penyebab kebiasaan hukum merupakan unsur penting lainnyayang harus dipertimbangkan dalam upaya membina kesadaran hukum rakyat demiterwujudnya taat hukum, mengenai dan menyadari wewenang dan tangggung jawabnya selaku rakyat yang ideal (Djoko \& Warsito, 2019). 
Taraf kultur kesadaran hukum pada rakyat bagi wewenangdan tanggungjawabnya kepada hukum memeiliki korelasi pada taraf pembelajaran dan prosedur sosialisasi mengenai hukum tersebut. Di sisi bobot, kompeten dan apersepsi para pemegang tonggak hukum jua termasuk perkara yang wajib diluruskan.

\section{SIMPULAN}

Dampak dari aspek yuridis normative dan aspek teknis administratif, terjadi kendala dalam regulasi fidusia menurut ketentuan UU No.42 Tahun 1999 mengenai Jaminan Fidusia, dikarenakan tidak sesuainya muatan hukum (materi hukum) UU Jaminan Fidusia pada pasal-pasal materi muatannya, sehingga terjadi beberapa penafsiran interpretasi dari pasal-pasal satu dengan pasal lainnya, yang berakibat tidak ada kepastian hukum bahkan bisa terjadi konflik hukum. Belum tersedianya struktur hukum (kelembagaan fidusia) Kantor Pendaftaran Fidusia (KPF) maupun dukungan sumber daya manusia pelaksanaannya, sertalegal kultur (budaya hukum) karena tingkatketaatan hukum masyarakat yang masih rendah dan belum sepenuhnya menyadari wewenang dan tanggungiwabnya sebagai rakyat Indonesia. Pendaftaran jaminan fidusia, apabila aktanya dibawah tangan, maka kreditur penerima fidusia merupakan kreditur biasa dan tidak dapat dijadikan dasar menuntut hak preferentnya seandainya terjadi wanprestasi oleh debitur dan harus membuktikan dahulu bahwa sudah terjadi utang piutang. Sedangkan apabila akta jaminan fidusia dibuat secara notariil, maka kreditur disebut objek fidusia berdasar akta notaris, namun tidak sebagai kecenderungan karena tidak didaftar di Kantor Pendaftaran Fidusia (KPF), jadi sebagai kreditur biasa. Hal semacam ini tentunya tidak ada kepastian hukum. Bagaimana apabila terjadi wanprestasi adanya kepastian hukum tentunya jikalau benda jaminan fidusia besertaakta notariat. kemudian langsung dilegal kan pada Kantor Pendaftaran Fidusia (KPF), disaat pendaftaran maka seketika itu pula haknya sebagai kreditur cenderung lahir, kepada kreditur adanya hak yang sangat banyak mengenai pelaksanaan bendajaminan pada setiap pihakyang menjadi tanggung jawabnya.

\section{DAFTAR PUSTAKA}

Adnyaswari, N. N. A., Nyoman, N., \& Putrawan, S. (2018). Kekuatan Hukum Akta Jaminan Fidusia Yang Tidak Didaftarkan. Jurnal Kertha Semaya, 6(12).

Benuf, K., \& Azhar, M. (2020). Metodologi Penelitian Hukum sebagai Instrumen Mengurai Permasalahan Hukum Kontemporer. Gema Keadilan, 7(1), 20-33.

Danari, E. L. (2020). Penyelesaian Sengketa Kontrak Fidusia Menurut Undang-Undang Nomor 42 Tahun 1999 Tentang Jaminan Fidusia. Lex Privatum, 8(2).

Djoko, S., \& Warsito, F. X. (2019). Etika Moral Berjalan, Hukum Jadi Sehat. Binamulia Hukum, 7(1), $26-35$.

Lestari, S., \& Bahmid, B. (2020). Tanggung Jawab Hukum Terhadap Penghasut untuk Melakukan Unjuk Rasa yang Berakibat Anarkis. Jurnal Pionir, 6(2), 253-259.

Merista, O. (2016). Hak Cipta Sebagai Obyek Jaminan Fidusia Ditinjau Dari Undang-Undang Nomor 28 Tahun 2014 Tentang Hak Cipta Dan Undang-Undang Nomor 42 Tahun 1999 Tentang Jaminan Fidusia. Veritas et Justitia, 2(1), 204-230.

Nekit, K., \& Zubar, V. (2020). Fiduciary management and fiduciary ownership in the post -Soviet countries: experience of Ukraine, Republic of Moldova, Republic of Belarus and Russian Federation. Trusts \& Trustees.

Nurhan, N. (2018). ANALISIS YURIDIS PENDAFTARAN JAMINAN FIDUSIA UNTUK MENEGUHKAN KEPASTIAN HUKUM. Ius Civile: Refleksi Penegakan Hukum Dan Keadilan, 1(1). 
Putra, F. M. K. (2016). Karakteristik Pembebanan Jaminan Fidusia Pada Benda Persediaan dan Penyelesaian Sengketa Saat Debitor Wanprestasi. Perspektif: Kajian Masalah Hukum Dan Pembangunan, 21(1), 34-47.

Rufaida, K. K. (2019). Tinjauan Hukum Terhadap Eksekusi Objek Jaminan Fidu sia Tanpa Titel Eksekutorial Yang Sah. Refleksi Hukum: Jurnal Ilmu Hukum, 4(1), 21-40.

Setianingrum, R. B. (2016). Mekanisme Penentuan Nilai Appraisal Dan Pengikatan Hak Cipta Sebagai Objek Jaminan Fidusia. Jurnal Media Hukum, 23(2), 229-238.

Setiono, G. C. (2018). Jaminan kebendaan dalam proses perjanjian kredit perbankan (tinjauan yuridis terhadap jaminan benda bergerak tidak berwujud). Transparansi Hukum, 1(1).

Setiono, G. C., \& Sulistyo, H. (2021). CIDERA JANJI DALAM PERJANJIAN KREDIT JAMINAN FIDUSIA. Transparansi Hukum, 4(1).

Siallagan, H. (2016). Penerapan Prinsip Negara Hukum di Indonesia. Sosiohumaniora, 18(2), 122 128.

Suari, D. A. A., \& Gorda, A. A. A. N. S. R. (2020). Penyelesaian Kredit Macet Dengan Jaminan Fidusia di Bank Rakyat Indonesia Cabang Renon. Soumatera Law Review, 3(1), 73-80.

Triargono, W. (2017). PERLINDUNGAN HUKUM BAGI KREDITUR DENGAN JAMINAN FIDUSIA. Universitas Islam Indonesia.

Yasir, M. (2016). Aspek Hukum Jaminan Fidusia. SALAM: Jurnal Sosial Dan Budaya Syar-I, 3, 75-92. 